\title{
EDITORIAL
}

\section{Challenges in the Implementation of COVID-Appropriate Behavior}

\author{
Subhash C Parija ${ }^{1}$, Abhilash Sasidharannair Chandrakumari ${ }^{2}$ \\ SBV Journal of Basic, Clinical and Applied Health Science (2021): 10.5005/jp-journals-10082-03116
}

COVID-19 pandemic has raised a potential catastrophic threat to the human life. Ever since the pandemic outbreak began the late 2019 , the virus has spread rapidly across the globe like wildfire. Since there is no specific drug or treatment for the COVID-19 patients, the only way to protect the humankind is by preventing the spread of transmission.

India has adopted distinct approaches as a part of COVIDappropriate behavior (CAB) to curtail the spread of COVID-19, such as contact tracing, quarantine, social distancing, frequent handwashing, mandatory facemask in all public places, lockdown, travel measures, vaccination, etc. Ensuring appropriate implementation of these measures at all levels is responsibility of all members of the society, and it requires complete cooperation, support, and collective action from all.

The effective implementation of these $C A B$ measures in the larger community would be feasible only after curbing several barriers. Recognizing and understanding these indicators is a definite challenge. The factors that influence the implementation of CABs can be categorized into cultural, administration, and healthcare related. Major challenges under the cultural factors include lack of community awareness, negligence and ignorance about the pandemic, misconception about the disease, fear of isolation from the public, religious beliefs, and public stigmatization. $^{1}$

Challenges in the administrative commitment comprise shortage of healthcare workers, lack of role models for creating community awareness, lack of uniform law and strict enforcement of World Health Organization regulations, lack of supportive supervision, and lack of proper resources. ${ }^{2,3}$

Healthcare-related challenges involve working in a very new context, overcrowding at the hospital and medical stores, asymptomatic patients, low population to bed ratio, acute need for oxygen, partial implementation of door-to-door delivery, lack of proper communication between medical personnel and public, and false perception about vaccination..$^{4,5}$

Though the barriers addressed here cannot be generalized globally, this can serve as a springboard for the experts to carry out further researches and to analyze the severity of individual challenges. Prioritizing the challenges based on the severity will aid the administrators and the policymakers to overcome those
${ }^{1}$ Department of Community Medicine, Sri Balaji Vidyapeeth, Puducherry, India

${ }^{2}$ Shri Sathya Sai Medical College and Research Institute, Sri Balaji Vidyapeeth, Chengalpattu, Tamil Nadu, India

Corresponding Author: Abhilash Sasidharannair Chandrakumari, Shri Sathya Sai Medical College and Research Institute, Sri Balaji Vidyapeeth, Chengalpattu, Tamil Nadu, India, Phone: +91 9894346193, e-mail: abey4aris@gmail.com

How to cite this article: Parija SC, Chandrakumari AS. Challenges in the Implementation of COVID-Appropriate Behavior. J Basic Clin Appl Health Sci 2021;4(2):31.

Source of support: Nil

Conflict of interest: None

indicators by giving due attention and effective implementation of CAB. In addition, targeted community awareness, shared responsibility, and collective action of people would lead to a better outcome.

\section{References}

1. Maqbool A, Khan NZ. Analyzing barriers for implementation of public health and social measures to prevent the transmission of COVID-19 disease using DEMATEL method. Diab Metab Syndr 2020;14(5):887892. DOI: 10.1016/j.dsx.2020.06.024.

2. Sidamo NB, Hussen S, Shibiru T, Girma M, Shegaze M, Mersha A, et al. Exploring barriers to effective implementation of public health measures for prevention and control of COVID-19 pandemic in Gamo Zone of Southern Ethiopia: using a modified Tanahashi model. Risk Manage Healthc Policy 2021;14:1219. DOI: 10.2147/RMHP. S297114.

3. https://www.timesnownews.com/india/article/govt-fully-alert-tocontrol-the-increasing-number-of-corona-cases-rajasthan-healthminister-raghu-sharma/654869.

4. https://www.timesnownews.com/health/article/5-dangerouscovid-19-vaccine-myths-busted-never-believe-suchmisinformation/748363.

5. https://www.timesnownews.com/india/article/india-s-productioncapacity-of-medical-oxygen-more-than-consumption-states-to-bemapped-to-sources-govt/745354.

(c) The Author(s). 2021 Open Access This article is distributed under the terms of the Creative Commons Attribution 4.0 International License (https:// creativecommons.org/licenses/by-nc/4.0/), which permits unrestricted use, distribution, and non-commercial reproduction in any medium, provided you give appropriate credit to the original author(s) and the source, provide a link to the Creative Commons license, and indicate if changes were made. The Creative Commons Public Domain Dedication waiver (http://creativecommons.org/publicdomain/zero/1.0/) applies to the data made available in this article, unless otherwise stated. 